\title{
Retardation of Sodium Exchange in Dog Erythrocytes by Physiological Concentrations of Aldosterone, in Vitro *
}

\author{
Colette Spach $\dagger$ and David H. P. Streeten \\ (From the Department of Medicine, State University of New York, Upstate Medical Center, \\ Syracuse, $N . Y$.)
}

It is well known that aldosterone, by its effects on renal tubular reabsorption of sodium, plays an important role in reducing renal excretion of sodium, both in response to sodium deprivation and in pathological states of fluid retention (2). Excessive aldosterone output has been shown to be associated with reduced sodium concentrations in sweat and saliva (3). It is probable that this mineralocorticoid, like desoxycorticosterone acetate (DCA) (4), reduces the sodium content of the feces (5). Woodbury and Koch (6) have shown that aldosterone significantly decreases the intracellular sodium concentration in the brain and skeletal muscle of mice. It is unlikely that these actions of the hormone on different cells and tissues in the body are entirely secondary to the action on the renal tubule. Indeed, aldosterone has been shown to influence sodium transport in toad bladder in vitro (7) and to have a direct stimulatory effect on the contractility of smooth muscle (8) and myocardium (9). This evidence that the steroid acts directly on a variety of different tissues led us to study its action on sodium transport between the plasma and the cells of the blood. Previously unsuccessful attempts to demonstrate an effect of aldosterone on erythrocytes $(10-12)$ might have resulted from technical difficulties in measuring sodium exchange, both because human erythrocytes contain only small amounts of sodium that exchange very slowly (13) and because the blood used presum-

* Submitted for publication February 8, 1963; accepted October 14, 1963.

Presented in part at the 54th annual meeting of the American Society for Clinical Investigation, May 1962 (1).

This study was supported by grants from the U. S. Public Health Service (A-4488(S1) and the National Science Foundation (G-19164).

$\dagger$ Present address: Institut de Physiologie, Faculté de Médecine, Université de Strasbourg, France. ably contained normal concentrations of aldosterone. Since the sodium concentration in canine erythrocytes $(110 \mathrm{mEq}$ per $\mathrm{L})$ is far higher than that in human erythrocytes ( $10 \mathrm{mEq}$ per $\mathrm{L}), \mathrm{dog}$ blood was used in the present studies. In an attempt to increase the sensitivity of the blood cells to the effects of added aldosterone, studies were also made on blood obtained from dogs in which aldosterone deficiency had been induced by bilateral adrenalectomy.

\section{Methods}

Blood was obtained from the same male mongrel dog ( $\operatorname{dog}$ I) for most of the following experiments, which were performed over a period of several weeks before and after the animal had been subjected to total bilateral adrenalectomy. After the adrenalectomy, the dog was fed ad libitum and maintained in good health by injections of hydrocortisone (12.5 mg twice a day), physiological saline (500 $\mathrm{ml}$ subcutaneously daily), and DCA in sesame oil ( $2.5 \mathrm{mg}$ twice a day). The DCA was withheld while the experiments on the effects of aldosterone were being performed $1,3,8,14$, and 16 days after the last dose of DCA. Additional studies were performed on a female dog (dog II) 3 to 10 months after bilateral adrenalectomy and 3 to 18 days after stopping treatment with DCA. Because of severe blood loss during the adrenalectomy in dog I and frequent experimental venesections from 3 weeks thereafter, the hematocrit was lower in the experiments performed after the adrenalectomy (20.8 to $28.5 \%$ ) than before the operation (38.9 to $46.1 \%$ ). In all of the experiments performed on blood from dog II, the hematocrit was above $40 \%$.

The method for studying sodium fluxes was essentially that of Solomon $(11,14)$. To $30 \mathrm{ml}$ of fresh, heparinized blood, glucose was added (50 $\mathrm{mg}$ in $1 \mathrm{ml} 0.9 \%$ $\mathrm{NaCl}$ solution). The blood, contained in four $10-\mathrm{ml}$ stoppered beakers, was shaken for 2 hours at $37^{\circ} \mathrm{C}$ in a Dubnoff metabolic shaker. A humidified stream of $95 \% \mathrm{O}_{2}$ and $5 \% \mathrm{CO}_{2}$ was passed through the beakers.

Fifteen minutes after the beginning of the incubation, $\mathrm{Na}^{22} \mathrm{Cl}$ was added to the blood in each beaker $(0.006 \mu \mathrm{c}$ in $0.02 \mathrm{ml} 0.9 \% \mathrm{NaCl}$ per $\mathrm{ml}$ of blood). At the same 


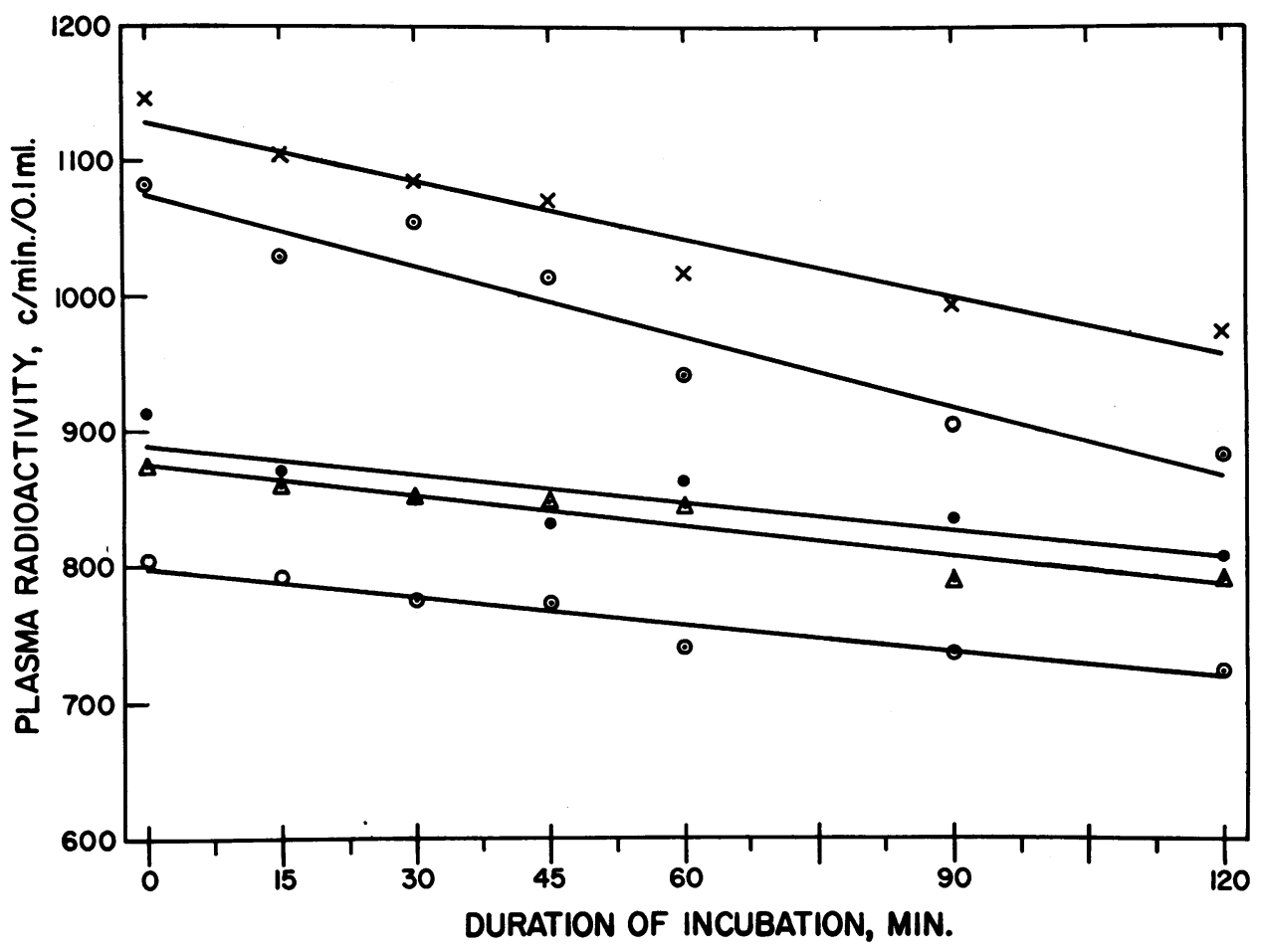

Fig. 1. Decline of plasma radioactivity with time during incubation with $\mathrm{NA}^{22} \mathrm{Cl}_{\mathrm{L}}$ OF BLOOD FROM DOG I AFTER ADRENALECTOMY. No aldosterone was added to the reaction vessels in these experiments.

time, varying amounts of $d, l$-aldosterone ${ }^{1}$ dissolved in $95 \%$ ethanol and diluted $1: 200$ with $0.9 \%$ saline were added by micropipette to three of the four beakers. Sufficient amounts of the ethanol and saline vehicle of the steroid were added to make the ethanol and saline concentration equal in all four beakers. Samples of blood were withdrawn from the beakers immediately after rapid mixing, at 15-minute intervals for 1 hour and every 30 minutes thereafter for 2 hours. Each sample was immediately centrifuged for 8 minutes, so that the time which elapsed between the addition of $\mathrm{Na}^{22}$ and the separation of the first samples of plasma was between 10 and 11 minutes. Duplicate $0.1-\mathrm{ml}$ plasma samples were counted in a well-type scintillation counter. The duplicate counts almost always agreed to within $\pm 1 \%$ of their mean, with occasional differences of up to $\pm 1.5 \%$. These differences, which included the pipetting errors, only slightly exceeded the expected range of variation attributable to counting alone for the 10,000 counts made on each sample.

The hematocrit (by Wintrobe method ${ }^{2}$ ) and plasma sodium concentration (by flame photometry) were determined on blood obtained from each of the beakers at

1 Aldosterone was kindly furmished by Dr. C. H. Sullivan, Ciba Pharmaceutical Co., Summit, N. J.

2 Wintrobe hematocrit tubes manufactured by Kimble Glass, Toledo, Ohio. the beginning and end of the experiment. Generally there was no measurable change in hematocrit, but in two of the experiments, when evaporation of plasma raised the hematocrit by more than $1 \%$, the plasma radioactivity counts were corrected for this loss of water on the assumption that evaporation was constant through-

TABLE I

Effect of adrenalectomy on sodium flux in blood of dog $I$ without added aldosterone

\begin{tabular}{cc}
\hline \hline & Na flux \\
\hline & $m E q / L$ cells $/ h r$ \\
1 Before adrenalectomy & 12.9 \\
(4 experiments) & 14.8 \\
& 13.3 \\
& 13.5 \\
Mean \pm SEM* & $13.88 \pm 0.42$ \\
& 27.4 \\
2 After adrenalectomy & 22.9 \\
(5 experiments) & 18.5 \\
& 25.2 \\
& 17.5 \\
Mean \pm SEM & $22.30 \pm 1.90$ \\
p 1 vs. 2: & $<0.01$ \\
\hline
\end{tabular}

* Standard error of the mean. 
RETARDATION OF ERYTHROCYTE SODIUM EXCHANGE BY ALDOSTERONE IN VITRO

TABLE II

Effects of added aldosterone on sodium flux before adrenalectomy in dog I

\begin{tabular}{|c|c|c|c|c|c|c|c|}
\hline \multirow{2}{*}{$\begin{array}{c}\text { Exp't } \\
\text { no. }\end{array}$} & \multirow{2}{*}{$\begin{array}{c}\text { Concen- } \\
\text { tration } \\
\text { of added } \\
d \text {-aldosterone }\end{array}$} & \multirow[b]{2}{*}{$\mathrm{Na}$ flux } & & \multicolumn{2}{|c|}{ Plasma $\mathrm{Na}$ concentration } & \multicolumn{2}{|c|}{ Hematocrit } \\
\hline & & & & $0^{\circ}$ & $2^{\circ}$ & $0^{\circ}$ & $2^{\circ}$ \\
\hline & $\underset{\text { plasma }}{\mu g / L}$ & $\begin{array}{l}m E q / L \\
\text { cells/hr }\end{array}$ & \multirow[b]{3}{*}{ Mean: } & \multicolumn{2}{|c|}{$m E q / L$} & \multicolumn{2}{|c|}{$\%$} \\
\hline $\begin{array}{l}1 \\
2\end{array}$ & $\begin{array}{l}0 \\
0\end{array}$ & $\begin{array}{l}12.9 \\
14.8\end{array}$ & & & & & \\
\hline $\begin{array}{l}3 \\
4\end{array}$ & $\begin{array}{l}0 \\
0\end{array}$ & $\begin{array}{l}14.3 \\
13.5\end{array}$ & & 147.8 & 149.3 & 42.6 & 42.6 \\
\hline $\begin{array}{l}3 \\
4 \\
4 \\
3^{*} \\
1 \\
2 \\
4 \\
1 \\
2^{*} \\
1 \\
2\end{array}$ & $\begin{array}{r}1.4 \\
6.6 \\
13.2 \\
13.7 \\
29.9 \\
30.9 \\
32.2 \\
61.5 \\
62.8 \\
186 \\
190\end{array}$ & $\begin{array}{r}13.8 \\
13.5 \\
8.6 \\
10.1 \\
9.9 \\
11.8 \\
7.0 \\
6.4 \\
9.9 \\
5.6 \\
7.9\end{array}$ & & $\begin{array}{l}144 \\
139 \\
146 \\
153 \\
153 \\
138 \\
158 \\
153 \\
141 \\
149 \\
144\end{array}$ & $\begin{array}{l}144 \\
140 \\
145 \\
\\
156 \\
138 \\
157 \\
156 \\
\\
152 \\
143\end{array}$ & $\begin{array}{l}39.3 \\
45.8 \\
46.1 \\
38.9 \\
41.5 \\
43.4 \\
45.6 \\
42.3 \\
43.4 \\
42.4 \\
43.6\end{array}$ & $\begin{array}{l}39.4 \\
46.0 \\
46.2 \\
39.0 \\
43.0 \\
43.4 \\
45.8 \\
44.0 \\
43.5 \\
44.0 \\
43.5\end{array}$ \\
\hline Mean: & & & & 146.9 & 147.9 & 42.9 & 43.4 \\
\hline SEM :† & & & & \pm 0.7 & \pm 2.5 & \pm 0.73 & \pm 0.72 \\
\hline $\mathrm{p}:$ & & & & & & & \\
\hline
\end{tabular}

* Data from one reaction vessel in experiment 3 were omitted because of visible hemolysis.

$\dagger$ Standard error of the mean.

out the experiment. The results of these two experiments did not differ in any other way from the results of all the other experiments in which no change in hematocrit was recorded. Visible evidence of hemolysis was present at the end of three experiments, the results of which were discarded. In a few of the other studies, absence of significant hemolysis was confirmed by measurements of optical density at $416 \mathrm{~m} \mu$ in a Coleman junior spectrophotometer. ${ }^{3}$

Separate experiments were designed to verify by direct observation that changes in plasma radioactivity reflected changes in the uptake of $\mathrm{Na}^{22}$ by the erythrocytes. In these studies, approximately $1-\mathrm{ml}$ blood samples, removed at the same times as before, were centrifuged for $1 \frac{1}{2}$ minutes at $3,000 \mathrm{rpm}$. The plasma was removed, and the cells were washed with $1 \mathrm{ml} 0.9 \% \mathrm{NaCl}$ solution and centrifuged again. The cells were then taken up in capillary tubes that were sealed with wax and centrifuged in an International microcapillary centrifuge 4 for 5 minutes. The capillary tubes were then broken at a point just below the buffy coat and weighed. The erythrocytes were allowed to hemolyze in $1 \mathrm{ml}$ of distilled water, and their activity was counted twice to 10,000 counts. The capillary tubes were then washed, dried in an oven, and weighed again. Thus the $\mathrm{Na}^{22}$ content of the erythrocytes could be calculated in counts per minute per gram of cells.

3 Coleman Instruments, Maywood, Iil.

4 International Equipment, Boston, Mass.
Calculation of results. Since the duration of incubation was only 2 hours in these experiments, the rate of decline of plasma radioactivity depended almost entirely on influx of $\mathrm{Na}^{22}$ into the cells, $\mathrm{Na}^{22}$ efflux being of relatively small magnitude. The sodium exchange rates were therefore calculated by the initial slope method of Sheppard and Martin (15). This involved determining, by the method of least squares, the regression coefficient, $b$, of the fall in plasma radioactivity with time. Then $\mathrm{Na}$ influx $=\mathrm{b} \times$ plasma $\mathrm{Na}$ concentration $/ \mathrm{p}_{\mathrm{o}}$, where $p_{o}=$ plasma radioactivity at zero time. Sodium influx was expressed in milliequivalents per liter of cells per hour by multiplying by the factor 1 -hematocrit/hematocrit.

\section{Results}

The fall in the plasma radioactivity with time, measured on blood from dog I in the five experiments done after the adrenalectomy, and without the addition of aldosterone to the reaction vessels, is shown in Figure 1. The reasonable fit of the counts to the calculated regression confirms both the expectation arrived at on theoretical grounds and the experience from previous studies $(11,13)$. The sodium fluxes were reasonably constant in the experiments conducted in the absence of added aldosterone, both preopera- 


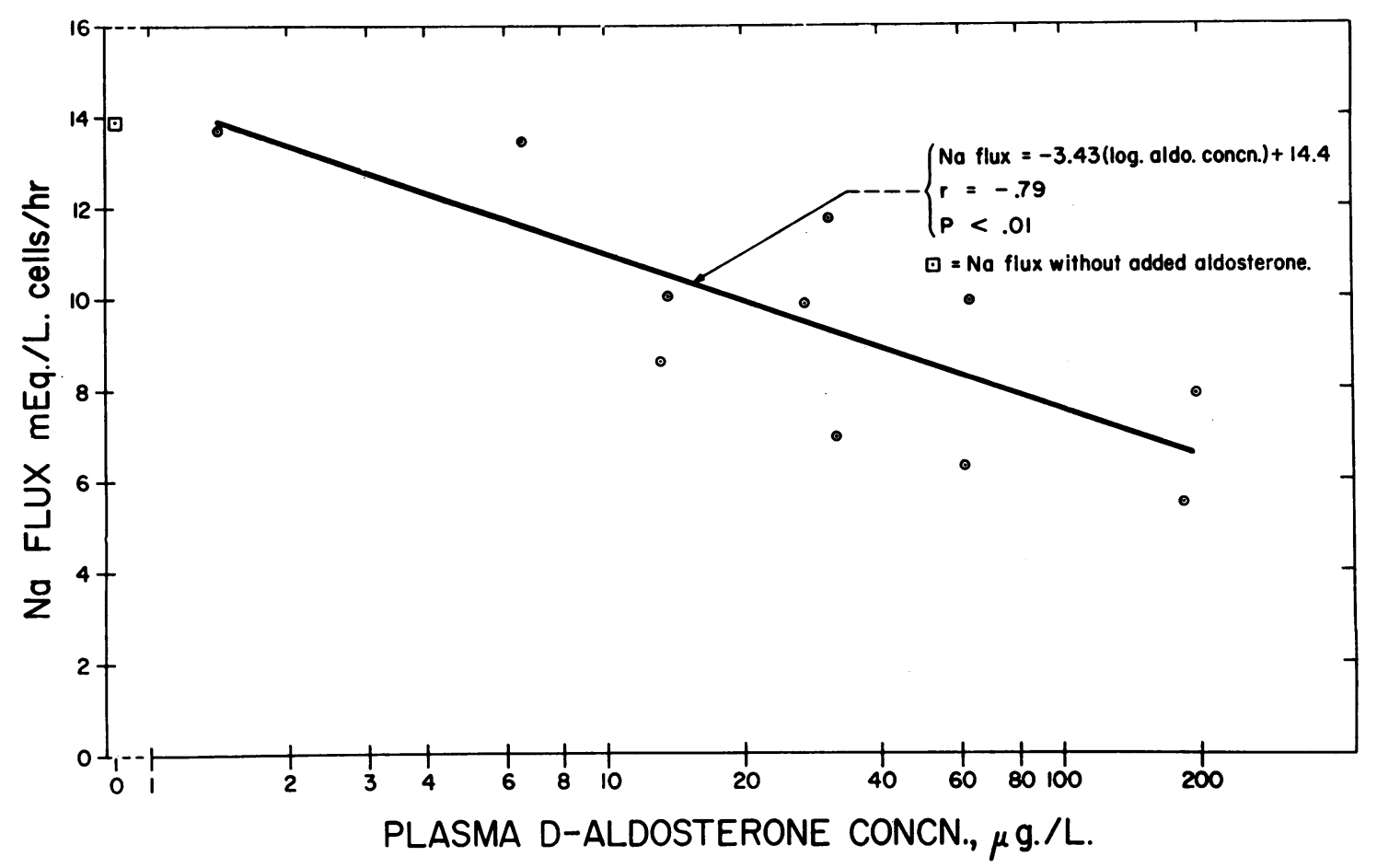

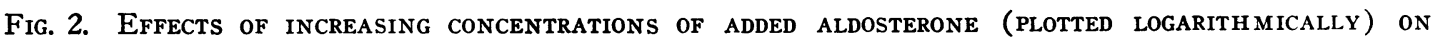
SODIUM FLUX IN BLOOD CELLS OF DOG I BEFORE ADRENALECTOMY.

tively and after adrenalectomy, as shown in Table I. Since there was no overlap between the results of the sodium fluxes before the adrenalectomy and the consistently higher sodium fluxes after the adrenalectomy, this increase in sodium flux after the adrenalectomy was highly significant ( $\mathrm{p}<0.01$ by $t$ test).

Effects of aldosterone added in vitro. a) Before adrenalectomy. The sodium fluxes observed when aldosterone was added in a variety of concentrations to the blood in the reaction vessels before adrenalectomy in $\operatorname{dog} \mathrm{I}$ are shown in Table II. A downward trend in the magnitude of sodium flux with increasing concentrations of aldosterone is evident. This relationship is depicted as a dose-response curve in Figure 2. The calculated regression representing the effects of aldosterone on sodium flux, $\mathrm{Na}$ flux $=-3.43$ (log aldosterone concentration $)+14.4$, was highly significant statistically $(\mathrm{r}=-0.79, \mathrm{p}<0.01)$.

b) After adrenalectomy. The effects of aldosterone on sodium flux between plasma and cells after adrenalectomy are shown in Table III and depicted as a log dose-response curve in Figure 3.
From the data it is evident that there is an exponential relationship between sodium flux and concentration of aldosterone. Na flux $=-21.74(\mathrm{log}$ aldosterone concentration) +9.96 , which is highly significant $(r=-0.97, p<0.001)$ between aldosterone concentrations of 0.24 and $1.5 \mu \mathrm{g}$ per L. Concentrations of $d$-aldosterone above 1.5 $\mu \mathrm{g}$ per $\mathrm{L}$ appeared to induce maximal inhibitory effects, consistently reducing sodium flux rates to low values (2.6 to $6.4 \mathrm{mEq}$ per $\mathrm{L}$ cells per hour).

The significance and the magnitude of the effects of aldosterone on sodium flux could be shown in another way, by comparing the decline in plasma radioactivity with time in five control experiments with the comparable data in the eight experiments in which the blood was incubated with $d$-aldosterone concentrations of 2.0 to $23.1 \mu \mathrm{g}$ per $\mathrm{L}$ plasma (Table IV). Plasma radioactivity had declined further after 15 minutes' incubation in the absence of added aldosterone (falling from 874 to $847 \mathrm{cpm}$ per $0.1 \mathrm{ml}$ ) than after 2 hours' incubation in the presence of 2.0 to $23.1 \mu \mathrm{g}$ per $\mathrm{L} d$-aldosterone (falling in these experiments 


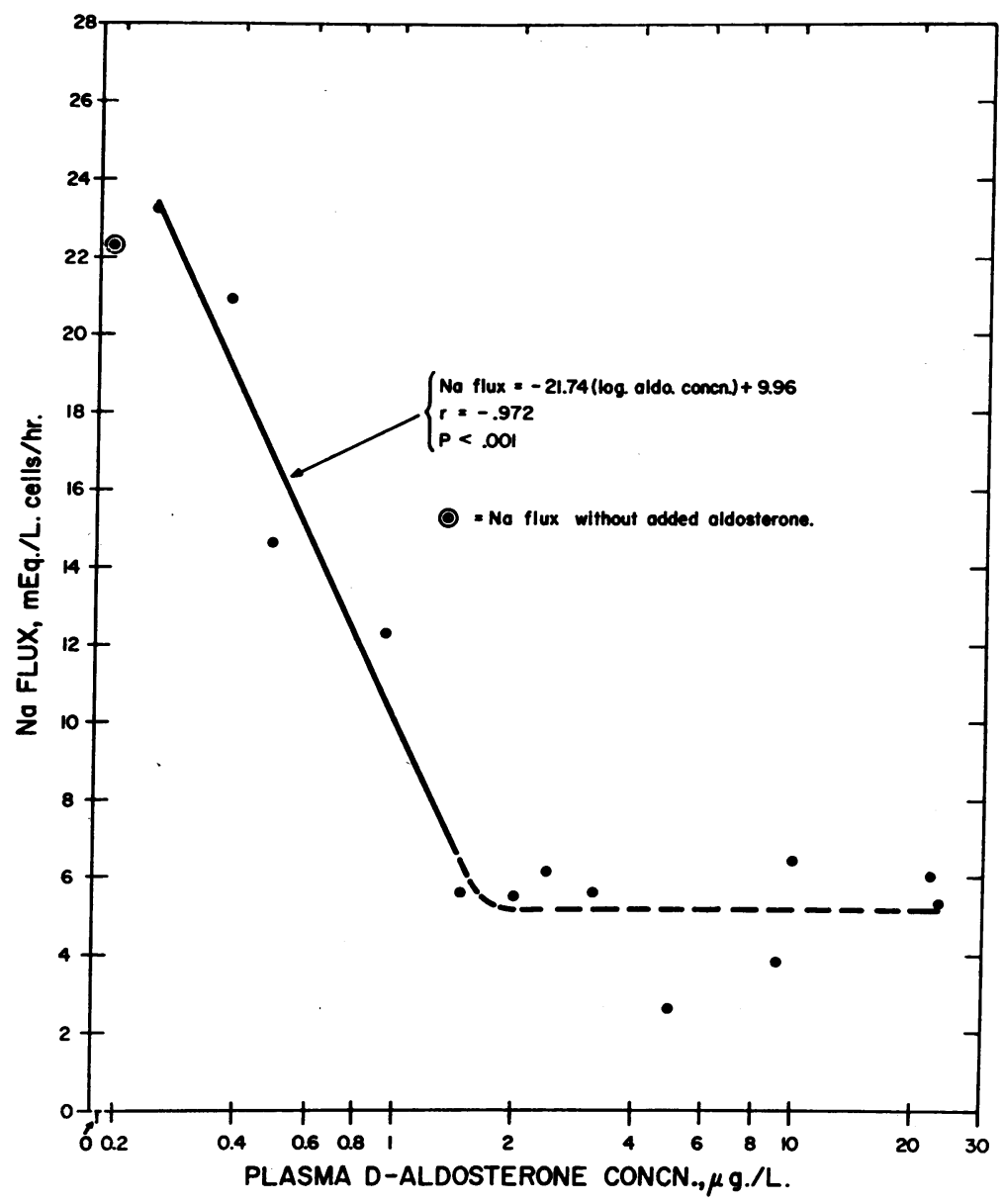

Fig. 3. EFFECTS OF INCREASING CONCENTRATIONS OF ADDED ALDOSTERONE (PLOTTED LOGARITHMICALLY) ON SODIUM FLUX IN BLOOD CELLS OF DOG I AFTER ADRENALECTOMY.

from 870 to $851 \mathrm{cpm}$ per $0.1 \mathrm{ml}$ ). These data were compared by the $t$ test after expressing each value of plasma radioactivity as a percentage of the initial (i.e., zero-time) value in that experiment. Figure 4 shows the clear separation between the radioactivity levels with and without added aldosterone and the significant retardation of the decline of plasma radioactivity with time in the presence of aldosterone at all stages of the 2-hour incubation.

In a separate series of experiments on blood from dog II after adrenalectomy, the same effects of varying concentrations of aldosterone were observed. The data obtained from both dogs after adrenalectomy are compared in Figure 5. Here the ordinate represents the percentage change (compared with control data) in the regression coefficient, $b$, of the line calculated to fit the declining plasma radioactivities with time at each concentration of added aldosterone. Expressed in this way, the data from both dogs indicate an exponential relationship between the percentage change in the regression coefficient and the plasma concentration of added $d$-aldosterone between 0.35 and $2.4 \mu \mathrm{g}$ per $\mathrm{L}$. Increases in plasma $d$-aldosterone concentrations above 2.4 or $3.15 \mu \mathrm{g}$ per L produced slightly further reduction in $\mathrm{b}$ in $\operatorname{dog} \mathrm{I}$.

Direct measurement of $\mathrm{Na}^{22}$ uptake by erythrocytes. Direct measurement of radioactivity in the erythrocytes of dog II showed a linear increase in erythrocyte $\mathrm{Na}^{22}$ and specific activity (since erythrocyte sodium concentration remained constant) with time of incubation (Figure 6). 


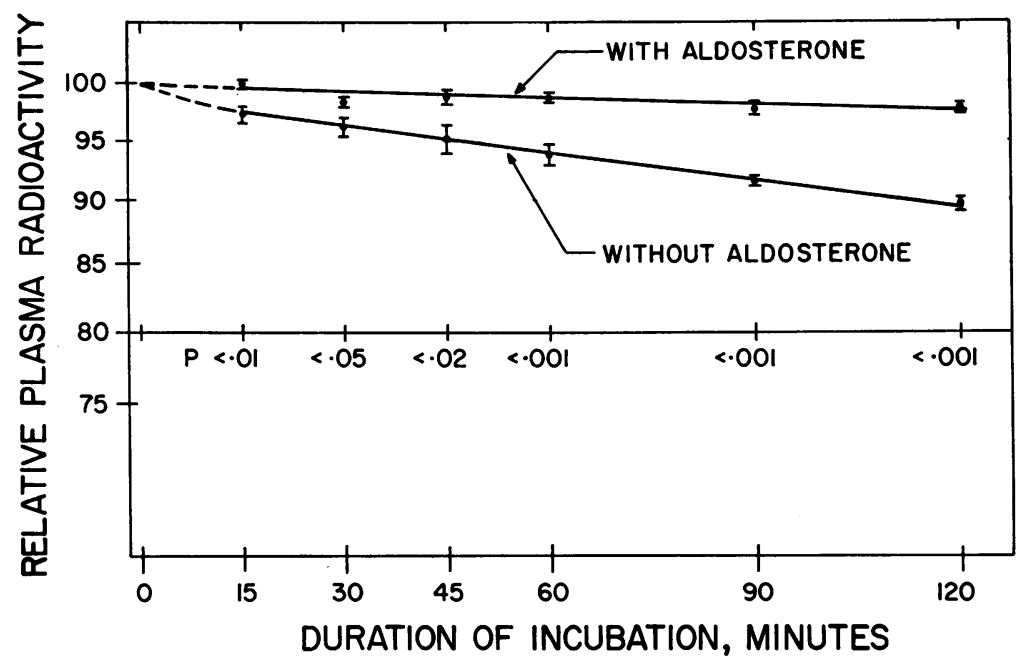

Fig. 4. Decline in plasma radioactivity with duration of incubaTION OF BLOOD FROM DOG I. In each experiment observed plasma radioactivity levels were expressed as a percentage of the level at zero time. The lines represent the calculated regressions of the mean relative plasma radioactivity on time for all experiments performed in the absence of added aldosterone (lower line) and all experiments in which at least $2 \mu \mathrm{g} d$-aldosterone per $\mathrm{L}$ plasma was added to the blood of the adrenalectomized dog (upper line). Vertical bars represent standard errors of the mean. The $p$ values indicate the levels of significance of the differences between the means at $15,30,45,60,90$, and 120 minutes after the commencement of the incubations.

TABLE III

Effects of added aldosterone on sodium flux after adrenalectomy in dog I

\begin{tabular}{|c|c|c|c|c|c|c|c|}
\hline \multirow{2}{*}{$\begin{array}{l}\text { Exp't } \\
\text { no.* }\end{array}$} & \multirow{2}{*}{$\begin{array}{c}\text { Concen- } \\
\text { tration } \\
\text { of added } \\
d \text {-aldosterone }\end{array}$} & \multirow[b]{2}{*}{$\mathrm{Na}$ flux } & & \multicolumn{2}{|c|}{ Plasma Na concentration } & \multicolumn{2}{|c|}{ Hematocrit $\dagger$} \\
\hline & & & & $0^{\circ}$ & $2^{\circ}$ & $0^{\circ}$ & $2^{\circ}$ \\
\hline & $\underset{\text { plasma }}{\mu g / L}$ & $\underset{\text { cells } / h r}{m E q / L}$ & \multicolumn{3}{|c|}{$m E q / L$} & \multicolumn{2}{|c|}{$\%$} \\
\hline $\begin{array}{l}1 \\
2 \\
3 \\
4 \\
5\end{array}$ & $\begin{array}{l}0 \\
0 \\
0 \\
0 \\
0\end{array}$ & $\begin{array}{l}27.4 \\
22.9 \\
18.5 \\
25.2 \\
17.5\end{array}$ & Mean: & 144.9 & 145.4 & 24.5 & 24.8 \\
\hline $\begin{array}{l}3 \\
4 \\
3 \\
2 \\
5 \\
5 \\
4 \\
1 \\
5 \\
1 \\
3 \\
1 \\
2\end{array}$ & $\begin{array}{c}0.24 \\
0.37 \\
0.48 \\
0.93 \\
1.47 \\
1.99 \\
2.41 \\
3.15 \\
4.93 \\
9.11 \\
9.88 \\
22.2 \\
23.1\end{array}$ & $\begin{array}{r}23.3 \\
20.9 \\
14.6 \\
12.3 \\
5.6 \\
5.5 \\
6.2 \\
5.6 \\
2.6 \\
3.8 \\
6.4 \\
6.0 \\
5.3\end{array}$ & & $\begin{array}{l}139 \\
152 \\
142 \\
146 \\
143 \\
142 \\
152 \\
148 \\
142 \\
147 \\
145 \\
149 \\
148\end{array}$ & $\begin{array}{l}139 \\
152 \\
142 \\
145 \\
144 \\
142 \\
152 \\
148 \\
142 \\
149 \\
144 \\
148 \\
148\end{array}$ & $\begin{array}{l}25.5 \\
23.9 \\
26.1 \\
24.7 \\
27.4 \\
28.5 \\
24.0 \\
20.8 \\
27.6 \\
21.5 \\
27.6 \\
21.2 \\
24.4\end{array}$ & $\begin{array}{l}25.3 \\
24.0 \\
26.1 \\
25.0 \\
27.4 \\
28.8 \\
23.9 \\
21.0 \\
27.4 \\
21.5 \\
27.5 \\
21.2 \\
24.5\end{array}$ \\
\hline Mean: & & & & 145.8 & 145.8 & 24.9 & 24.9 \\
\hline
\end{tabular}

* Data from one reaction vessel in experiments 2 and 4 omitted because of visible hemolysis.

$\dagger$ Lowered hematocrits in these experiments resulted from severe blood loss during the adrenalectomy. 


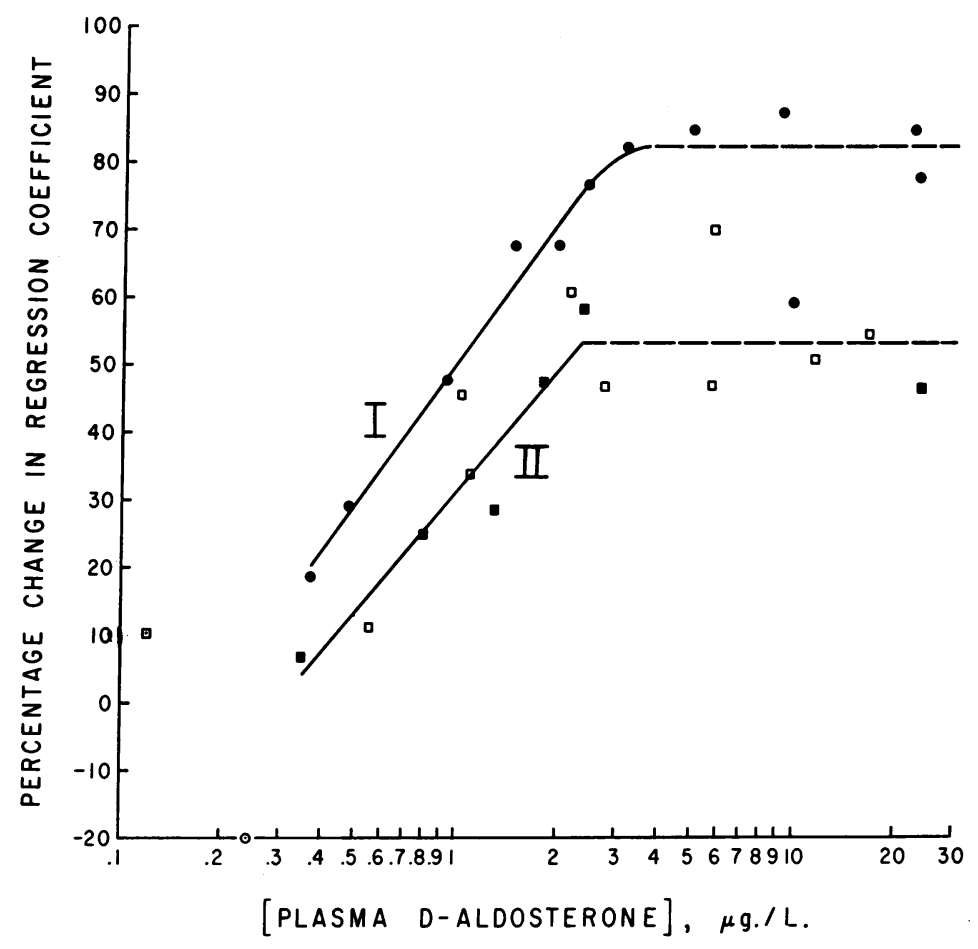

Fig. 5. Log dOSE-RESPONSE ReLATIONShIPS BeTWEen PLASMA CONCENTRATION OF ADDED D-ALDOSTERONE AND CHANGE (FROM THE CONTROL VALUE) IN THE REGRESSION COEFFICIENT OF THE LINE REPRESENTING DECLINE OF PLASMA RADIOACTIVITY WITH DURATION OF INCUBATION. The two lines depicted were calculated to fit the data obtained on dogs I (solid circles) and II (solid squares) after bilateral adrenalectomy. The estimating equations were I: $\mathrm{Y}=70.2 \times-19.5(\mathrm{r}=+0.937, \mathrm{p}<$ $0.01)$ and II : $\mathrm{Y}=59.2 \times-28.0 \quad(\mathrm{r}=+0.964, \mathrm{p}<0.01)$. The open squares depict data subsequently obtained on dog II by direct counts of erythrocyte radioactivity (expressed as percentage change in regression coefficients of lines representing rise in erythrocyte radioactivity with time) in the presence of varying concentrations of aldosterone added to the plasma.

TABLE IV

Plasma radioactivity in experiments after adrenalectomy in dog $I$

\begin{tabular}{|c|c|c|c|c|c|c|c|c|c|c|c|c|c|c|c|}
\hline \multirow[b]{3}{*}{ Time } & & & & & & & \multicolumn{9}{|c|}{ Experiments with maximally effective concentrations of aldosterone } \\
\hline & \multirow{2}{*}{\multicolumn{5}{|c|}{$\begin{array}{l}\text { Control experiments } \\
\text { No added aldosterone }\end{array}$}} & \multicolumn{10}{|c|}{$d$-Aldosterone concentration, $\mu g / L$} \\
\hline & & & & & & Mean & 2.0 & 2.4 & 3.2 & 4.9 & 9.1 & 9.9 & 22.2 & 23.1 & Mean \\
\hline $\min$ & & & $c p m$ & & & \multicolumn{10}{|c|}{$c p m$} \\
\hline 0 & 802 & 872 & 913 & 858 & 923 & 874 & 913 & 838 & 803 & 863 & 829 & 1066 & 832 & 819 & 870 \\
\hline 15 & 794 & 859 & 870 & 820 & 894 & 847 & 913 & 845 & 803 & 862 & 829 & 1048 & 836 & 816 & 869 \\
\hline 30 & 776 & 852 & 850 & 827 & 885 & 838 & 886 & 827 & 802 & 856 & 802 & 1036 & 829 & 829 & 858 \\
\hline 45 & 774 & 848 & 832 & 803 & 889 & 829 & 891 & 835 & 798 & 860 & 841 & 1029 & 820 & 815 & 861 \\
\hline 60 & 741 & 842 & 863 & 786 & 862 & 819 & 893 & 829 & 799 & 863 & 815 & 1037 & 824 & 821 & 860 \\
\hline 90 & 737 & 790 & 837 & 780 & 850 & 799 & 885 & 822 & 802 & 858 & 817 & 1028 & 811 & 778 & 850 \\
\hline 120 & 724 & 791 & 806 & 760 & 833 & 783 & 884 & 820 & 782 & 847 & 815 & 1022 & 821 & 818 & 851 \\
\hline
\end{tabular}



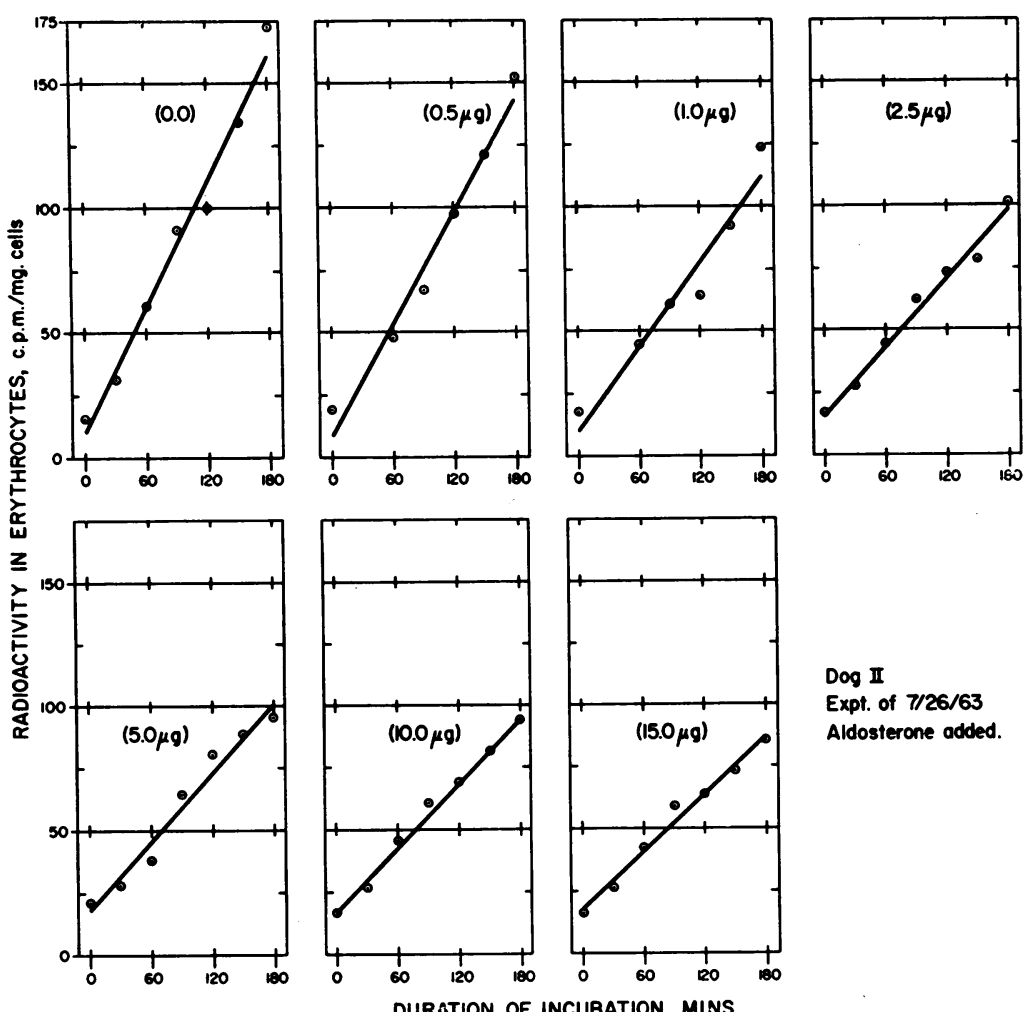

Dog II

Expt. of $7 / 26 / 63$

Aldosterone added.

Fig. 6. Rise IN ERYTHROCYTE RADIOACTIVITY WITH DURATION OF INCUBATION, IN PRESENCE OF VARYING CONCENTRATIONS OF D-ALDOSTERONE IN THE PLASMA. Erythrocyte radioactivity is expressed as counts per minute per milligram cells. Concentrations of $d$-aldosterone are indicated in micrograms per liter (in parentheses). Calculated regressions are shown. Data were obtained from an experiment on dog II after adrenalectomy.

Aldosterone retarded the accumulation of $\mathrm{Na}^{22}$ in the erythrocytes. The percentage changes induced by increasing doses of aldosterone, in the slopes of the regressions relating erythrocyte radioactivity with time of incubation, bore a dose-response relationship very similar to that found by the measurements of plasma radioactivity in previous experiments on blood from the same dog (Figure 5, II).

Net sodium movement between plasma and cells. Tables III and IV show that no consistent change in hematocrit or plasma sodium concentration took place during the 2-hour incubation period. The product, serum sodium times 1 - hematocrit, too, showed no consistent trend in the course of any of the experiments. There was, thus, no evidence of any net sodium movement into or out of the cells over the 2 -hour period of the experiments.

\section{Discussion}

The rates of sodium exchange between plasma and erythrocytes in the normal dog studied in these experiments (mean, $13.88 \mathrm{mEq}$ per $\mathrm{L}$ cells per hour) are in good agreement with the mean values ( $13 \mathrm{mEq}$ per $\mathrm{L}$ cells per hour) reported by Sheppard, Martin, and Beyl (13). The present results indicate that the rate of sodium exchange between the plasma and the cells of canine blood is signficantly retarded by aldosterone added in vitro. The effect of the aldosterone in retarding sodium flux increases exponentially with increasing steroid concentrations, but in blood from the intact animal can be demonstrated with certainty only when concentrations of aldosterone are used that probably exceed physiological levels. These levels might well be reached under pathological conditions, however, when aldosterone 
secretion rates may show as much as a fivefold rise (16).

After bilateral adrenalectomy, while the dogs were maintained on hydrocortisone and saline, aldosterone had significant effects on sodium flux rates in far lower concentrations than before the operation. The normal plasma levels of aldosterone in human subjects have been found to be from 0.2 to $2.0 \mu \mathrm{g}$ per $\mathrm{L}(17,18)$, whereas the plasma level in the blood of cattle was even higher, $3.5 \mu \mathrm{g}$ per L (19). Since aldosterone secretion rates are reported to be at least as high in dogs, 0.216 to $0.513 \mu \mathrm{g}$ per $\mathrm{kg}$ per hour $(20)$, as in man, plasma concentrations of the steroid in peripheral blood might be expected to be similar in these two species. Recent studies in dogs have shown that the plasma concentration of aldosterone varies between $0.02 \mu \mathrm{g}$ per $\mathrm{L}(21)$ and 0.2 $\mu \mathrm{g}$ per $\mathrm{L}(22)$ and was increased to $0.9 \mu \mathrm{g}$ per $\mathrm{L}$ by constriction of the inferior vena cava in the thorax (21). The effects of aldosterone on sodium exchange are therefore demonstrable at steroid concentrations which are within the physiological range for human subjects and probably within the physiopathological range for dogs as well. It was of some interest to find that the sodium exchange rates measured in the blood of the dog before adrenalectomy correspond with the exchange rates observed at plasma concentrations of $d$-aldosterone of 0.45 to $0.6 \mu \mathrm{g}$ per L added in vitro to the blood studied after adrenalectomy. The fact that these plasma concentrations of aldosterone fall well within the range reported in human and dog plasma suggests that the aldosterone in circulating blood has a measurable effect on sodium exchange between the plasma and the cells. Moreover, the addition of aldosterone in concentrations at or only slightly above the upper limit of this range reduced sodium exchange as much as four times, suggesting again that this action of aldosterone is probably of physiological as well as pathological significance and is not a mere laboratory artifact.

The amount of extracellular sodium in the system in vitro did not change during the course of the 2-hour incubation. This suggests that aldosterone retarded sodium efflux to the same extent as it retarded sodium influx, so that no net movement of sodium occurred in either direction in these experiments. The relatively short duration of the experiments, however, makes it hazardous to draw more than tentative conclusions from these results. Further studies will be needed to demonstrate whether longer periods of incubation would show some net movement of sodium under control conditions and whether aldosterone might change either the rate or the direction of this net movement. Such an action of the steroid would be necessary to explain the effects of aldosterone administration on the content of sodium in brain and muscle in vivo (6), but it is not known whether aldosterone affects erythrocyte sodium content in the same way.

The most likely mechanism whereby aldosterone might retard the disappearance of $\mathrm{Na}^{22}$ from the plasma is by inhibition of the rate of sodium influx into the erythrocytes or leukocytes or platelets, or all three. The direct observations on canine erythrocytes confirm the inhibitory action of aldosterone on sodium influx and indicate that this action is exercised to a large extent on the erythrocytes rather than on the other formed elements of the blood. Unfortunately, it is not known whether sodium influx into the sodium-rich erythrocytes of the dog takes place by simple diffusion alone or might involve an active process. The findings, however, raise the interesting possibility that the action of aldosterone on cellular sodium content might be brought about by impeding the inward movement of sodium into cells rather than by accelerating the "sodium pump," which is postulated to be actively extruding sodium from cells.

Almost all of the previous studies $(10,11,12)$ on the effects of aldosterone on erythrocyte sodium exchange have been done on human blood with negative results. Friedman and Friedman (23) are the only authors who have succeeded in demonstrating an action of aldosterone on human erythrocytes. Their studies showed that $d, l$-aldosterone in concentrations of 500 to $2,000 \mu \mathrm{g}$ per $L$ reduced the rate of sodium uptake of erythrocytes during cooling and the rate of sodium loss from refrigerated erythrocytes during rewarming at $37^{\circ} \mathrm{C}$. The concentrations of aldosterone used in these experiments were probably at least 125 times above physiological levels. Our own observation of an inhibitory effect of physiological concentrations of aldosterone is in qualitative agreement with the results of Friedman and Friedman (23). 


\section{Summary}

1) When the blood of a male dog was incubated with glucose, $\mathrm{Na}^{22} \mathrm{Cl}$, and varying concentrations of aldosterone added in vitro, the sodium exchange between the cells and the plasma was significantly retarded by concentrations of $d$-aldosterone between 61.5 and $107 \mu \mathrm{g}$ per L plasma.

2) Similar studies on blood from the same dog and a second dog after adrenalectomy and while on maintenance treatment with hydrocortisone and sodium chloride showed that between $d$-aldosterone concentrations of 0.2 and $2.0 \mu \mathrm{g}$ per $\mathrm{L}$ plasma (approximately the physiological range), there was a highly significant inverse log doseresponse relationship between steroid concentrations and sodium flux rates. When the plasma concentration of $d$-aldosterone was increased from 2.0 to $23.1 \mu \mathrm{g}$ per L, however, sodium flux rates were decreased no further, but were maintained at values approximately one-fourth those measured in the absence of added aldosterone.

3) In the absence of added aldosterone, sodium flux was consistently higher after adrenalectomy (17.5 to $27.4 \mathrm{mEq}$ per $\mathrm{L}$ of cells per hour) than before the operation (12.9 to $14.8 \mathrm{mEq}$ per $\mathrm{L}$ of cells per hour).

4) The observed effect of physiological or pathological concentrations, or both, of aldosterone on sodium flux suggests that aldosterone may play an important role in controlling sodium exchange between the plasma and the erythrocytes of the dog.

\section{Acknowledgments}

Grateful acknowledgment is made to Dr. Robert Meyer, who adrenalectomized the dogs. Miss Mary Kearney performed the studies in dog II.

\section{References}

1. Streeten, D. H. P., and C. Spach. Retardation of sodium flux in dog erythrocytes by physiological concentrations of aldosterone in vitro (abstract). J. clin. Invest. 1962, 41, 1403.

2. Luetscher, J. A., Jr. Studies of aldosterone in relation to water and electrolyte balance in man. Recent Progr. Hormone Res. 1956, 12, 175.

3. Conn, J. W. Primary aldosteronism, a new clinical syndrome. J. Lab. clin. Med. 1955, 45, 3.
4. Berger, E. Y., G. P. Quinn, and M. A. Homer. Effect of desoxycorticosterone on the colon: its relation to the action of cation exchange resins in man. Proc. Soc. exp. Biol. (N. Y.) 1951, 76, 601.

5. Milne, M. D., R. C. Muehrcke, and I. Aird. Primary aldosteronism. Quart. J. Med. 1957, 26, 317.

6. Woodbury, D. M., and A. Koch. Effects of aldosterone and desoxycorticosterone on tissue electrolytes. Proc. Soc. exp. Biol. (N. Y.) 1957, 94, 720.

7. Crabbé, J. Stimulation of active sodium transport by the isolated toad bladder with aldosterone in vitro. J. clin. Invest. 1961, 40, 2103.

8. Streeten, D. H. P., B. I. Hirschowitz, K. S. Henley, and H. M. Pollard. Effects of adrenocortical steroids on the propulsive motility of small intestine. Amer. J. Physiol. 1957, 189, 108.

9. Sayers, G., and N. Solomon. Work performance of a rat heart-lung preparation: standardization and influence of corticosteroids. Endocrinology 1960, 66, 719.

10. Glynn, I. M. The action of cardiac giycosides on sodium and potassium movements in human red cells. J. Physiol. (Lond.) 1957, 136, 148.

11. Solomon, A. K. The permeability of the human erythrocyte to sodium and potassium. J. gen. Physiol. 1952, 36, 57.

12. Sulser, F., and W. Wilbrandt. Die Wirkung von Corticosteroiden und Herzglykosiden auf Ionentransporte am Erythrocyten. Helv. physiol. pharmacol. Acta 1957, 15, C37.

13. Sheppard, C. W., W. R. Martin, and G. Beyl. Cation exchange between cells and plasma of mammalian blood. II. $\mathrm{Na}$ and $\mathrm{K}$ exchange in the sheep, dog, cow and man, and the effect of varying plasma potassium concentration. J. gen. Physiol. 1951, 34, 411.

14. Streeten, D. H. P., and A. K. Solomon. The effect of ACTH and adrenal steroids on $\mathrm{K}$ transport in human erythrocytes. J. gen. Physiol. 1954, 37, 643.

15. Sheppard, C. W., and W. R. Martin. Cation exchange between cells and plasma of mammalian blood. I. Methods and application to potassium exchange in human blood. J. gen. Physiol. 1950, 33, 703.

16. Carpenter, C. C. J., J. O. Davis, and C. R. Ayers. Concerning the role of arterial baroreceptors in the control of aldosterone secretion. J. c in. Invest. 1961, 40, 1160.

17. Simpson, S. A., and J. F. Tait. Recent progress in methods of isolation, chemistry, and physiology of aldosterone. Recent Progr. Hormone Res. $1955,11,183$. 
18. Ayers, P. J., O. Garrod, W. H. Pearlman, S. A. S. Tait, J. F. Tait, and G. Walker. The use of $\left[16^{8} \mathrm{H}\right]$ aldosterone in studies on human peripheral blood. Ciba Foundation Colloquia on Endocrinology 1957, 11, 309.

19. Wettstein, A., and G. Anner. Advances in the field of adrenal cortical hormones. Experientia (Basel) 1954, 10, 397.

20. Farrell, G. Regulation of aldosterone secretion. Physiol. Rev. 1958, 38, 709.

21. Ayers, C. R., J. O. Davis, F. Lieberman, C. C. J. Carpenter, and M. Berman. The effects of chronic hepatic venous congestion on the metabolism of $d, l$-aldosterone and $d$-aldosterone. $\mathrm{J}$. clin. Invest. 1962, 41, 884.

22. Bojesen, E., and H. Degn. A double isotope derivative method for the determination of aldosterone in peripheral plasma. The effect of adrenalectomy on aldosterone level in anaesthetized dogs. Acta endocr. (Kbh.) 1961, 37, 541.

23. Friedman, S. M., and C. L. Friedman. Effect of aldosterone and hydrocortisone on sodium in red cells. Experientia (Basel) 1958, 14, 452. 